可視化情報 Vol.21 Suppl. No.1（2００１年 7月） 竹島 由里子, 大塚 理恵子（お茶の水女子大学）

\title{
Volume Skeletonization and Fleshing
}

\author{
Issei FUJISHIRO, Shigeo TAKAHASHI, Yuriko TAKESHIMA, Rieko OTSUKA
}

\begin{abstract}
This article presents the concept of volume skeletonization and fleshing as a generalized process of the traditional field value-dependent transfer function (TF) design. Volume skeletonization delineates the topological structure of a given volume dataset by means of a graph called volume skeleton tree (VST), which consists of volumetric critical points and their connectivity. Both locations of critical points and their critical field values in the VST are then passed to the phase of volume fleshing to accentuate color and opacity more adaptively in the design of TFs for comprehensible volume rendering. Visually pleasing visualization results show the feasibility of the present approach as a volume data mining tool.
\end{abstract}

Keywords: Visual data mining, Volume visualization, Volume rendering, Transfer function

\section{1 ボリュームデータマイニング}

種々の理工学問題に現れるボリュームデータの構造を 数学的手法に基づいて調查し, 特徴的な変化をもつ部分 を（半）自動的に特定することにより，ユーザをより高 度な価値判断に専念させられるようなメカニズムを提 供することを目的として, 藤代は文献 [1] で, ボリュー ムデータマイニング (Volume Data Mining: VDM)の 概念を提唱した. 実際文献 [2] では, ボリュームフィー ルドの大局的な解析に微分位相幾何学的知見を利用し たVDM 方式を提案している，そこではまず，フィール ド値の変化に伴い等值面がもつ位相の同值性が崩れる ような臨界フィールド值 (Critical Field Value: CFV) がノードとして抽出され, 同值な等値面をもつフィー ルド区間の位相を表現するレーブグラフをエッジの重 みとするハイパーレーブグラフ (Hyper Reeb Graph: HRG）が構成される. そして, 各 CFVに対応する不透 明度を相対的に僅かに上昇させるとともに，色相にも 不連続性をもたせるように伝達関数 (transfer function: $\mathrm{TF}$ ）を設計することにより，わかりやすいボリューム レンダリング結果が生成される.

続いて文献 [3] では，ボリュームデータの新たな骨 格抽出表現に基づくVDM 方式を提案した．そこでは HRGの代わりに，ボリュームフィールドに関する等值 面の位相変化をダイレクトにグラフ構造として表すボ リューム骨格木（Volume Skeleton Tree: VST）が利 用されている.VST は，ボリュームフィールド（4 次
元曲面）が位相的に変化する 4 種類の臨界点（critical point）とそれらの接続関係から構成される.VST は HRG ではとらえきれなかったボリュームデータの大局 的な特徵を効果的に表現できる利点をもっている。 ま た位相的に正しいVST を抽出する高速アルゴリズムが 存在する.さらに, VSTによって記述された臨界等值 面の包含関係を考慮し, 内側の CFV ほど不透明度を相 対的に高く設定することで，ボリュームレンダリング による視線方向の遮蔽作用に対しても, 強調効果が保 持できるなど，HRGに基づく方式に較べてVDMッー ルとしての利用価值が一層高められている.

本稿では，与えられたボリュームから VSTを抽出す るボリューム骨格化 (volume skeletonization) に続 いて，CFVだけでなく，等値面の位相変化が生じてい る特異点周囲の構造も同時に強調するために, 同一の 等値面上でも，特異点からの距離に応じて $\mathrm{TF}$ 值を制 御するボリューム肉付け（volume fleshing）とよば れる手法を提案する。フィールド值だけに依存して色 や半透明度を決定していた $\mathrm{TF}$ を，ボリュームの位相 構造に関連した位置情報にも依存するように拡張的に 定義することで，ボリュームの骨格化と肉付けは；従 来の $\mathrm{TF}$ 設計の過程を汎化したことになる.フィール ドだけでなく,フィールド導関数との組合せによって隣 接マテリアル境界を強調したり, セグメンテーション 効果を伴うような TF の設計方式は, Kindlmann ら [4] によって提案されているが，ボリューム内の空間位置に も依存するような $\mathrm{TF}$ 設計法はまだ報告されていない， 


\section{2 実 例}

次のような解析的ボリュームを例題として考える：

$$
\begin{aligned}
w= & f(x, y, z)=4 c^{2}\left((x-R)^{2}+(z-R)^{2}\right) \\
& -\left((x-R)^{2}+y^{2}+(z-R)^{2}+c^{2}-d^{2}\right)^{2} \\
& +4 c^{2}\left((x+R)^{2}+(z+R)^{2}\right) \\
& -\left((x+R)^{2}+y^{2}+(z+R)^{2}+c^{2}-d^{2}\right)^{2}
\end{aligned}
$$

ただし $, 0<d<c, c^{2}+d^{2} \geq 6 R^{2}$.

Fig. 1 は, この例題ボリュームを $c=0.6, d=0.5, R=$ 0.2 として作成し, $32^{3}$ ボクセルを用いて離散化したも のから，文献 [3] で開発されたツールを利用して抽出さ れた VST と, CFV 付近の等值面を描画したものであ る. 臨界点 $p_{1}, p_{2}\left(w=8 c^{2} d^{2}=0.72\right)$ で $2 つ$ 等值面が 現れ， $p_{3}, p_{4}\left(w=8 c^{2} d^{2}-16 R^{2}\left(c^{2}+d^{2}-4 R^{2}\right)=0.432\right)$ でそれらが併合し，トーラスを形成していく，その後， $p_{5}\left(w=-2\left(c^{2}-d^{2}\right)^{2}+8 R^{2}\left(c^{2}+d^{2}-R^{2}\right)=0.1582\right)$ で トーラスの穴が塞がる様子がわかる.

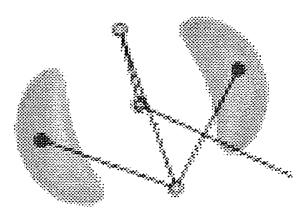

(a) $w=0.5606$

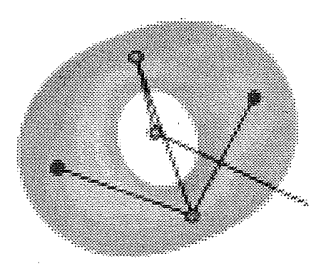

(c) $w=0.3117$

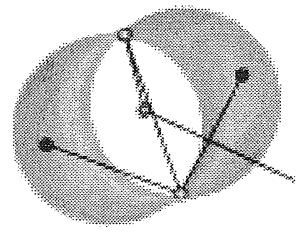

(b) $w=0.4320$

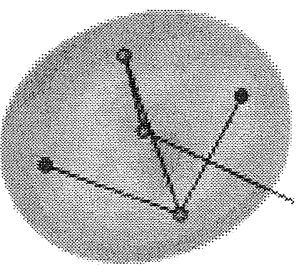

(d) $w=0.1582$
Fig. 1 例題ボリュームの VST と臨界等值面

AVS ver. 5.1 を用いた可視化実験結果を Fig. 2 に示 す. 同図 (a) は, 標準 TF (色: 色相に関して線形; 不透 明度：一定）を用いた結果である. 同図 (b) は, VSTに 記述された CFV を前節の方針に従って強調した TFで あり，同図 (c) がそれを用いて可視化した結果である. 同図 (a) と比較すれば，対象内部の位相構造が強調さ れて格段にわかりやすく描画されていることがわかる. 特に, 外側のサブボリュームによって隠されている, 内 部の 2 つのクロッサン状の等值面が, 階段状に不透 明度 TF を定義したことによって，視覚的に捕らえられ ている. 図 2(d) はさらに特異点の位置からの距離にも $\mathrm{TF}$ を依存させたボリューム肉付けの結果である. 対象 ボリュームの内部構造の鮮明さが増している.

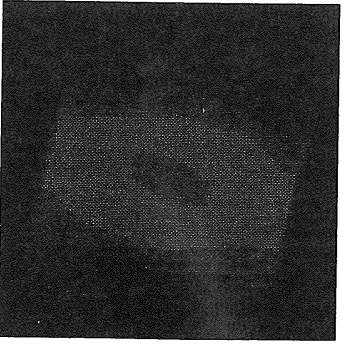

(a) 標準 TF を利用

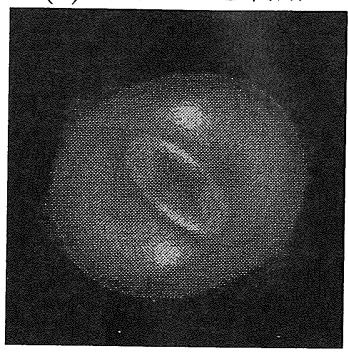

(c) (b)の TFを利用

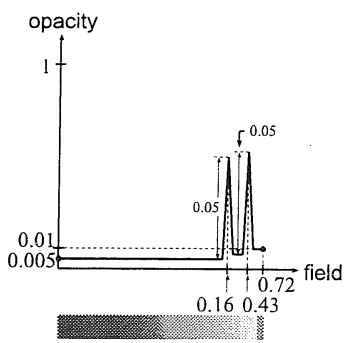

(b) 強調された TF
Fig. 2 例題ボリュームの可視化結果

\section{3 今後の課題}

前節で示した例題ボリュームの肉付けでは, AVSの ボリュームレンダラが, TFとしてフィールド值との対 応表しか受理しないため, 与えられたボリュームの臨 界等值面上のフィールド值を強制的に変更しているこ とに注意されたい。この事実は単なるソフトウェアの 整合処理にとどまらず，ボリューム肉付けを，位相骨 格に基づいたボリュームの平滑化（fairing）に拡張可能 なことを示唆している.

強調された TF を設計する際， CFV の特定だけでな く TF の形状を完全に自動設定するために, VST の構 造にボリューム相関性等の統計情報も加味して, 各種パ ラメタ值を算出するという重要な課題が残されている.

\section{参考文献}

[1] 藤代 一成:「ボリュームデータマイニング」, 可視化情報 学会誌, 20 Suppl.(1) (第 28 回可視化情報シンポジウ 厶講演論文集)，pp.161-162 (2000)

[2] I. Fujishiro, T. Azuma, Y. Takeshima, and S. Takahashi: "Volume data mining using 3D field topology analysis," IEEE CGEA A, 20(5):46-51 (2000).

[3] 竹島 由里子, 高橋成雄, 藤代一成:「ボリューム骨格抽 出とその伝達関数設計への応用」, 画像電子学会 Visual Computing 情報処理学会グラフィクスと CAD 合同シン ポジウム 2001 予稿集 (2001)

[4] G. Kindlmann and J. W. Durkin: "Semi-automatic generation of transfer functions for direct volume rendering," In Proc. Symposium on Volume Visualization, ACM SIGGRAPH, pp. 79-86, p. 170 (1998). 